\title{
Wyobraźnia autora i thumacza wobec pamięci kulturowej. O Wybrańcu Tomasza Manna i jego polskim przekładzie
}

\section{Wyobraźnia: między przekładem a pamięcią kulturową}

Wybraniec (Der Erwäblte) to jedna z ostatnich powieści Tomasza Manna. Wydana w roku 1951, powstała w końcowych latach pobytu pisarza na emigracji w USA i jest zjawiskiem unikatowym zarówno w XX-wiecznej literaturze światowej, jak i na tle całej spuścizny autora Czarodziejskiej góry. Inspirację do jej napisania znalazł Mann w XII-wiecznym eposie Hartmanna von Aue Gregorius der gute Sünder ${ }^{2}$ - legendzie o świętym Grzegorzu, średniowiecznej odmianie mitu o Edypie, którą niemiecki noblista interpretuje z pozycji twórcy $\mathrm{XX}$-wiecznego, między innymi w duchu psychoanalizy Freuda i Junga. W prozatorskiej parafrazie Hartmannowskich wersetów dochodzi do głosu sceptycyzm wobec wyczerpanych (zdaniem Manna) możliwości tradycyjnej, „mieszczańskiej” prozy. Już przy pisaniu Lotty w Weimarze czy cyklu o biblijnym Józefie - utworów otwarcie intertekstualnych i interdyskursywnych - ich autor wyrażał przekonanie, że pisarz współczesny skazany jest na epigonizm, grę konwencjami, montaż cytatów oraz specyficznie rozumianą parodię. Taką postawę twórczą potwierdza też Wybraniec ${ }^{3}$.

${ }^{\text {I }}$ Artykuł powstał w ramach projektu Pamięć, obcość i translacjajako kategorie przewodnie komparatystyki i literaturoznawstwa interkulturowego, finansowanego ze środków Narodowego Centrum Nauki (numer projektu: DEC-2013/09/B/ HS2 / 01192).

${ }^{2}$ Po raz pierwszy Mann zetknął się z motywem świętego grzesznika w późnośredniowiecznym zbiorze Gesta Romanorum oraz we francuskiej legendzie Vie de Saint-Grégoire; epos Hartmanna był dopiero kolejnym źródłem (por. H. Kuhn, Der gute Sünder - der Erwäblte?, w: Hartmann von Aue, Gregorius der gute Sünder. Mittelhocbdeutsch/Neubochdeutsch, tłum. B. Kippenberg, posłowie H. Kuhn, Stuttgart 2007, s. 236).

3 Studia archiwalne potwierdzają, że utwory napisane przez Manna pod koniec życia oraz te, które pozostały na etapie projektów, to prawie wyłącznie teksty parafrazujące tradycję literacką (np. konwencję powieści łotrzykowskiej w Wyznaniach hochsztaplera Feliksa Krulla) lub osnute wokół postaci autentycznych 
Czy sięganie po teksty kultury $\mathrm{z}$ dawnych epok, tworzenie przeróbek cudzych utworów zamiast własnych świadczyłyby o braku albo o kryzysie wyobraźni pisarza? Taki wniosek byłby pochopny. Należy podkreślić, że powieść Manna wyprzedziła swój czas: jej uwikłania intertekstualne i intersemiotyczne, gra cytatem, zawieszenie między legendą a fikcją historyczności ujawniają postmodernistyczne rozumienie literatury, a nawet antycypują narratywistyczną teorię historiografii lat 70.4. Z kolei poczucie kryzysu języka, potęgowane odcięciem pisarza emigranta od żywiołu ojczystej mowy, uruchomiło jego wyobraźnię językową. Swój niezwykły kształt artystyczny Wybraniec zawdzięcza unikatowemu eksperymentowi lingwistycznemu, który świadczy o nieprzeciętnej fantazji twórcy, badaczom nasuwa porównania $\mathrm{z}$ Jamesem Joyce'em ${ }^{5}$, zaś dla thumacza jest ambitnym wyzwaniem translatorskim.

Na przykładzie powieści Manna i jej tłumaczenia pióra Anny M. Linke, wydanego po raz pierwszy w roku 1960, postaram się pokazać, jak wyobraźnia twórcy - pisarza i tłumacza - wiąże się z przekładem i pamięcią kulturową. Kategorie te w kręgu humanistyki niemieckiej ostatnich dwóch dekad awansowały do rangi pojęć przewodnich (Leitbegriffe) kulturoznawstwa ${ }^{6}$. Jakie znaczenie zyskały one w literaturoznawstwie po zwrocie kulturowym?

Jak podkreśla Astrid Erll, pamięć można rozumieć dosłownie, metaforycznie i metonimicznie ${ }^{7}$; mówi się o pamięci indywidualnej, zbiorowej, społecznej, kulturowej. Literaturoznawcę interesuje pamięć indywidualna i społeczna jako temat dzieł literackich

z dawnych epok. Wśród niezrealizowanych planów znalazły się: dramat o Marcinie Lutrze, powieść o Erazmie z Rotterdamu, a także kontynuacja niedokończonego eposu Goethego o Achillesie (por. K. Schröter, Thomas Mann, Reinbek bei Hamburg 2005, s. 177).

${ }_{4}$ Pisałam o tym w artykule Postać charyzmatyczna a postać historyczna. Na przykladzie powieści Tomasza Manna „Wybraniec” i Güntera Grassa „Turbot”, w: Postaci charyzmatyczne w literaturze anglo-i niemieckojezycznej, red. G. Moroz, M. Ossowski, Olecko 2009.

5 Por. H.J. Weigand, Thomas Mann's „Gregorius”, „Germanic Revue” 1952, 27, nr 2, s. 89.

${ }^{6}$ O paradygmatycznym charakterze translacji - zob. D. Bachmann-Medick, „Cultural turns”. Neuorientierungen in den Kulturwissenschaften, Reinbek bei Hamburg 2009 (zwłaszcza Nacbwort zur 3. Auflage, s. 407-416); o pamięci A. Assmann, Gedächtnis als Leitbegriff der Kulturwissenschaften, w: Kulturwissenschaften: Forschung - Praxis - Positionen, red. L. Musner, G. Wunberg, Wien 2002, s. 27-45 oraz J. Assmann, Pamięć kulturowa: pismo, zapamiętywanie ipolityczna tożsamość w cyrwilizacjach starożytnych, tłum. A. Kryczyńska-Pham, wstęp, red. nauk. R. Traba, Warszawa 2008, s. 27.

7 Por. A. Erll, Kollektives Gedächtnis und Erinnerungskulturen, Stuttgart - Weimar 2011, s. 6. 
(klasyczny przykład to cykl Prousta), ale też literatura jako wyraz pamięci kulturowej: „pamięć literatury”, przez Renate Lachmann utożsamiana $\mathrm{z}$ intertekstualnością̧, oraz „pamięć o literaturze” w sensie tworzenia kanonu9 ${ }^{9}$ Tworzenie nawiązań intertekstualnych oraz kanonizacja dzieł literackich to różne formy obcowania z pamięcią kulturową ${ }^{\mathrm{To}}$. Literatura sama stanowi istotną treść pamięci kulturowej, a jednocześnie jej medium: odnosząc się do dawnych tekstów, nie pozwala o nich zapomnieć.

Definicje pamięci kulturowej zgodnie podkreślają jej dynamiczny charakter, procesualność i transformacyjność. Pamięć kulturowa obejmuje bowiem właściwy dla danej grupy i budujący jej tożsamość zasób tekstów, obrazów i rytuałów ${ }^{\mathrm{II}}$ - wiedzę zobiektywizowaną w mediach i formach symbolicznych ${ }^{12}$. Wiedzę tę Aleida Assmann określa jako pamięć archiwalną (Speichergedächtnis) i przeciwstawia ją pamięci funkcjonalnej (Funktionsgedächtnis): praktykom symbolicznym, mającym na celu utrwalenie wiedzy przez regularne jej powtarzanie ${ }^{\mathrm{I}}$. Pamięć kulturowa obejmuje zatem - obok stosunkowo stabilnych treści zapisanych w ,archiwum” - także pewien uwarunkowany kulturowo kontekst i społeczne formy ich przekazu ${ }^{\mathrm{I}}$, zakłada więc komunikację międzyludzką. Jak pisze Assmann, pamięć kulturowa, przekraczająca horyzont czasowy jednostkowej biografii, powstaje w drodze złożonych transformacji: doświadczenie indywidualne lub pokoleniowe musi ulec oddzieleniu od podmiotu doświadczającego i przeniknąć do zasobów ponadjednostkowej pamięci kulturowej, aby następnie - za pośrednictwem mediów i praktyk symbolicznych - mogły je zinternalizować kolejne jednostki ${ }^{15}$.

Ów społeczny wymiar pamięci kulturowej, jej tworzenie w nieustannych interakcjach między jednostkami, pokoleniami i epo-

${ }^{8}$ Por. R. Lachmann, Mnemotechnika i symulakrum, tłum. A. Pełka, w: Pamięć zbiorowa i kulturowa. Wspótczesna perspektywa niemiecka, red. M. Saryusz-Wolska, Kraków 2009, s. 308.

9 Por. A. Erll, op.cit., s. 74.

ro Por. ibidem, s. 178.

II Por. J. Assmann, Kollektives Gedächtnis und kulturelle Identität, w: Kultur und Gedächtnis, red. J. Assmann, T. Hölscher, Frankfurt am Main 1988, s. 15. Cyt. za: A. Nünning, Kulturelles Gedächtnis [hasło], w: Metzler Lexikon: Literatur- und Kulturtheorie. Ansätze - Personen - Grundbegriffe, red. A. Nünning, Stuttgart -Weimar 2008, s. 239.

I2 Por. D. Bering, Kulturelles Gedächtnis [hasło], w: Gedächtnis und Erinnerung. Ein interdisziplinäres Lexikon, red. N. Pethes, J. Ruchatz, Reinbek bei Hamburg 2001, s. 329.

${ }_{3}$ Por. A. Assmann, Der lange Schatten der Vergangenheit. Erinnerungskultur und Gescbichtspolitik, München 2006, s. 54-58.

${ }^{1} 4$ Por. A. Nünning, op.cit., s. 239.

${ }_{5}$ Por. A. Assmann, Der lange Schatten, s. 34. 
kami, nasuwa analogię z translacją. Drugie z omawianych tu pojęć dawno już przestało się mieścić $\mathrm{w}$ tradycyjnym Jakobsonowskim podziale na przekład interlingwalny, intralingwalny i intersemiotyczny. W sensie metaforycznym translacja to wszelkie formy działania społecznego służące porozumieniu między ludźmi ${ }^{\mathrm{I}}$. Zbieżność translacji i pamięci polega właśnie na komunikowaniu doświadczeń i przeżyć: transformacji pamięci neuronalnej w społeczną w relacjach międzypokoleniowych, „przekładzie” pamięci komunikatywnej na kulturową ${ }^{17}$. Dobór praktyk symbolicznych odpowiednich do wyrażania i utrwalania treści pamięci archiwalnej przypomina decyzję o strategii translatorskiej uwzględniającej horyzont oczekiwań odbiorcy. Podobnie - budowanie pamięci między generacjami wymaga „tłumaczenia” przeszłości na język zrozumiały i adekwatny do wrażliwości współczesnych. Odnosząc ten proces do pamięci jako intertekstualności, można z kolei powiedzieć, że zapis tekstów kultury w pamięci obecnych jej użytkowników polega na nieustannym aktualizowaniu, ożywianiu, translacji zasobów „archiwum” na język bliski człowiekowi XXI stulecia, na próbach niwelowania różnicy między "dawniej” a „dziś”, ,obcym” a ,swoim”.

Zarówno translacja, jak i obcowanie z pamięcią kulturową tworzenie, przypominanie i aktualizowanie tekstów kultury wymagają wyobraźni. Ta cecha ludzkiego umysłu definiowana jest różnie, jednak wspólnym mianownikiem wszystkich ujęć psychologicznych i filozoficznych jest uznanie jej twórczego charakteru, przejawiającego się pod różnymi postaciami: „[...] obrazowania czegoś, czego nie ma, funkcjonowania poznawczego w sytuacji możliwych alternatyw lub wymyślania nowych rozwiązań dla istniejących problemów” ${ }^{\text {I8 }}$. Podkreśla się też ścisły związek wyobraźni z pamięcią. Oba te mechanizmy kognitywne nieraz trudno od siebie odróżnić. Wyobraźnia generuje obrazy mentalne pod nieobecność bodźca wzrokowego ${ }^{19}$ - ale zdolność przywoływania tego, co nieobecne, jest przecież także zadaniem pamięci ${ }^{20}$. I choć pamięć intuicyjnie kojarzymy głównie z retro-

${ }^{16}$ Por. D. Bachmann-Medick, Einleitung: Übersetzung als Repräsentation fremder Kulturen, „Göttinger Beiträge zur internationalen Übersetzungsforschung”, t. 12: Übersetzungals Repräsentation fremder Kulturen, red. D. Bachmann-Medick, Berlin 1997, s. 4.

${ }^{17}$ Jak pisze Assmann, przypominanie i wspominanie jest tłumaczeniem „erinnern ist übersetzen” (por. A. Assmann, Der lange Schatten, s. 124).

${ }^{18}$ P. Markiewicz, P. Przybysz, Neuroestetyczne aspekty komunikacji wizualnej $i$ wyobraźni, w: Obrazy w umyśle. Studia nad percepcją $i$ wyobraźnia, red.

P. Francuz, Warszawa 2007, s. 136.

I9 P. Francuz, Wprowadzenie, w: Obrazy w umyśle, s. 11.

${ }^{20}$ Por. G. Butzer, Phantasie [hasło], w: Gedächtnis und Erinnerung, s. 437. 
spekcją, z odtwarzaniem fragmentów przeszłości, potrafi też ona działać jak fantazja, tworząc obrazy, rzeczy i wydarzenia, których nigdy nie było ${ }^{21}$. Dlatego utożsamianie pamięci wyłącznie z reprodukcją jest uproszczeniem - choć wypada zauważyć, że kreatywność pamięci ma charakter mimowolny, podczas gdy twórczość artystyczna polega na świadomym i celowym korzystaniu z fantazji.

Inną cechą wspólną pamięci i wyobraźni jest wybiórczość. Wyobraźnia zasadza się na umiejętności „swobodnej, spontanicznej selekcji oraz innowacyjnej kombinacji” wyobrażonych treści ${ }^{22}$. Ale również działanie pamięci polega na selekcji: zapominaniu, odrzucaniu, czy też wypieraniu pewnych wspomnień ${ }^{23}$.

Wyobraźnia jako potencjał estetyczny oraz „dyspozycja do dostrzegania wieloznaczności i wielości rozwiązań” ${ }^{24}$ stanowi z kolei niezbędny warunek przekładu. Praca wyobraźni w procesie lektury polega na ustawicznym wykraczaniu poza poziom odniesienia faktycznie istniejących znaków i konkretyzacji miejsc niedookreślenia ${ }^{25}$. Również tłumaczenie możliwe jest dzięki mechanizmom wyobrażeniowym. Wybór spośród wielu możliwych strategii przekładu i rozwiązań translatorskich wiąże się nierozłącznie z interpretacją i konkretyzacją.

Operowanie pojęciami wyobraźni, przekładu i pamięci kulturowej w interpretacji powieści Manna i polskiej wersji utworu wydaje się uzasadnione. Der Erwäblte to swoisty przekład pewnego tekstu kultury: eposu Hartmanna, jednego ze świadectw pamięci kulturowej kręgu zachodnioeuropejskiego. Mann tworzy palimpsest, nadpisując nad legendą własną historię - widzianą z perspektywy wieku XX - i uzupełniając ją o elementy wyobrażone, nieobecne ani w średniowiecznym eposie, ani w źródłach

${ }^{2 \pi}$ Jak cienka granica oddziela pamięć od wyobraźni, dowodzi zjawisko postmemory (por. np. N. Pethes, Kulturwissenschaftliche Gedächtnistheorien zur Einfübrung, Hamburg 2008, s. 157), a także trudność w odróżnieniu sugestywnych wyobrażeń - lebbafte Vorstellungen - od wspomnienia własnych doświadczeń leibhafte Erfabrungen (por. A. Assmann, Der lange Schatten, s. 132-133). Amerykański psycholog Daniel Schacter wśród siedmiu „grzechów pamięci” wymienia przypominanie sobie zdarzeń kontrafaktycznych (misattribution) oraz podatność na sugestię (suggestibility) - choć jego zdaniem rzekome słabości ludzkiej pamięci mają znaczenie pozytywne, jako „produkty uboczne” adaptacji mózgu w procesie ewolucji i cywilizacji, niezbędne człowiekowi do przeżycia (zob. D.L. Schacter, The Seven Sins of Memory. Insights from Psychology and Cognitive Neuroscience, „American Psychologist” 1999, t. 54, nr 3, s. 182-203).

${ }_{22}$ Por. Ph. Wolf, Einbildungskraft [hasło], w: Metzler Lexikon, s. 151.

${ }_{23} \mathrm{Jak}$ podkreślają teoretycy pamięci, z zapamiętywaniem nieodłącznie wiąże się zapominanie - to dwie strony tego samego medalu (por. np. A. Assmann, Der lange Schatten, s. 51).

${ }_{24}$ P. Markiewicz, P. Przybysz, op.cit., s. 136.

${ }_{25}$ Por. Ph. Wolf, op.cit., s. 151. 
historycznych, ani nawet w rzeczywistej przestrzeni geograficznej Europy. Nasuwa się pytanie, w jakim stopniu polskie tłumaczenie pokazuje palimpsestowość powieści Manna i wybraną przez pisarza praktykę symboliczną: specyficzną strategię translatorską aktualizującą treści pamięci archiwalnej.

\section{Der Erwäblte jako parodystyczny przekład pamięci kulturowej}

Odpowiedź wypada zacząć od wyjaśnienia, na czym polega owa strategia translatorska Manna, jak pisarz współczesny traktuje XII-wieczne źródło?

Legenda o świętym Grzegorzu (Gregoriusie) jest odmianą mitu o Edypie. Tytułowy wybraniec u Manna (jak bohater średniowiecznego eposu) to dziecko pochodzące $\mathrm{z}$ kazirodczego związku rodzeństwa - bliźniąt Sybilli i Wiligisa ${ }^{26}$, potomków rodu rządzącego księstwem Flandrii i Artois. Noworodek, widomy znak rodowej hańby, zostaje umieszczony w łódce i wypuszczony na morze. Matka wkłada do zawiniątka kosztowną materię, złote monety i tabliczkę $\mathrm{z}$ wyrytą informacją o szlacheckim, choć „grzesznym”, rodowodzie dziecka oraz prośbą, by ten, kto znajdzie chłopca żywego, wychował go i wykształcił, by umożliwić mu w przyszłości poznanie prawdy o jego pochodzeniu. Niemowlę znalezione u brzegów wyspy na kanale La Manche dostaje się pod opiekę mądrego opata. Gregorius zostaje wychowany jako rzekomy syn prostego rybaka, ale odbiera staranna edukację w klasztorze. Kiedy jako młodzieniec przypadkowo dowiaduje się o swej proweniencji, udaje się na poszukiwanie prawdziwych rodziców. Dociera do miasta Brügge, od wielu lat obleganego przez księcia Rogera, bezskutecznie starającego się o rękę księżnej Sybilli - matki Gregoriusa, która po porzuceniu dziecka i śmierci ukochanego brata postanowiła sama rządzić swym państwem i nigdy nie wychodzić za mąż. Bohater, niczego nieświadomy, uwalnia miasto od napastnika i żeni się z Sybillą. Gdy po kilku latach Gregorius dowiaduje się o pokrewieństwie $\mathrm{z}$ nią, opuszcza rodzinę $\mathrm{z}$ zamiarem odpokutowania grzechu. Przez siedemnaście lat tkwi przykuty do samotnej skały pośrodku jeziora, odżywiając się mitycznym „mlekiem ziemi”. W końcu zostaje uwolniony przez wysłanników z Rzymu, którzy odszukują go, aby - zgodnie z doznanym cudownym wi-

${ }^{26}$ Takie imiona bliźnięta noszą u Manna, u Hartmanna von Aue to postaci bezimienne, „brat i siostra”. 
dzeniem - obrać go głową Kościoła. Już jako papież, słynący z mądrości, dobroci i licznych cudów, Gregorius przyjmuje w Rzymie swoją matkę, która chce zrzucić z siebie brzemię winy i uzyskać rozgrzeszenie od najwyższej instancji kościelnej. Rozpoznawszy w „bardzo wielkim papieżu” swego męża i syna, Sybilla pozostaje w Rzymie jako przeorysza klasztoru. Wówczas też matka i syn wyznają sobie, że w głębi duszy oboje od początku przeczuwali swoje pokrewieństwo ${ }^{27}$.

Według Karla Stackmanna autor Wybrańca ujawnił się , w zupełnie nieoczekiwanej roli jako znakomity tłumacz z języka średniowysokoniemieckiego" ${ }^{28}$. Rzeczywiście, powieść można uznać za casus thumaczenia intralingwalnego. Słowo „przekład” należy tu jednak rozumieć znacznie szerzej: w kontekście estetycznym i kulturowym.

Sam Tomasz Mann w odniesieniu do swej powieści używa słowa „parodia” - jednak nie w potocznym znaczeniu, pojmowanego nie jako imitacja stworzona w celu prześmiewczym, deprecjonującym $^{29}$. Wprost przeciwnie: Mann do swoich wzorców ma stosunek aprobatywny. Parodię rozumie jako rodzaj nostalgicznej parafrazy, wynikającej z „miłości do ducha sztuki, w którego możliwości przestało się wierzyć” ${ }^{\circ}$. Według Manna kultura i parodia to pojęcia pokrewne, a najwyższe osiągnięcia literatury wieku XX możliwe są dzięki rekapitulacji, powtarzaniu „zachodnioeuropejskiego mitu" ${ }^{3}$. Parodia byłaby zatem repetycją pewnych treści kultury, ale bez ironicznego wydźwięku - inaczej mówiąc: przekładem zasobów pamięci kulturowej na język współczesny.

Ponadto parodię Manna powinno się też interpretować w kontekście refleksji przekładoznawczej Goethego. Według autora

${ }_{27}$ Tak dzieje się tylko u Manna, w eposie Hartmanna oboje pozostają całkowicie nieświadomi łączących ich więzów krwi.

${ }_{28}$ Por. K. Stackmann, „Der Erwäblte”. Thomas Manns Mittelalter-Parodie, „Euphorion” 1959, nr 53, s. 62. Thum. - K.L.

${ }_{29}$ Jeśli w Wybrańcu można mimo wszystko wyczuć ironię, to z pewnością nie odnosi się ona do Hartmannowskiego pierwowzoru, tylko do XX-wiecznych mód i nurtów intelektualnych, przede wszystkim do psychoanalizy. Jak dowodzi Bernward Plate, Wybraniec wyszydza irracjonalizm psychologii głębi, manifestuje krytykę antyidealizmu i antyintelektualizmu, a różne motywy powieści (np. tabliczka, ryba, cień, Królowa Niebios w modlitwie Sybilli, baranek) to ironiczne aluzje do pism psychologicznych i religijnych Carla G. Junga (por. B. Plate, Hartmann von Aue, Thomas Mann und die ,Tiefenpsychologie”, „Euphorion” $1984, \mathrm{nr} 78$, s. 31-59).

3o Cyt. za: U. Fix, Der Erwäblte, w: Das erzäblerische Werk Thomas Manns. Entstebungsgeschichte - Quellen - Wirkung, Berlin - Weimar 1976, s. 361. Tłum. K.L.

$3^{\text {I }}$ Por. K. Stackmann, op.cit., s. 70. 
Fausta twórca przekładu parodystycznego dąży do transferu na język docelowy nierozerwalnej całości, jaką stanowi „sens” oryginału i jego „forma”, w taki sposób, aby znaleźć dla niej rodzimy odpowiednik: tłumacz „dla każdego owocu żąda surogatu wyrosłego na jego własnym gruncie" ${ }^{2}$. Postulat taki można odnieść do parafrazy Manna: mimo językowej archaizacji jego tekst nawiązuje do XX-wiecznych dyskursów psychologicznych i filozoficznych, a więc owoców wyrosłych na gruncie współczesności33. Mann znajduje dla dawnej legendy formę przekazu adekwatną do wrażliwości artystycznej swoich czasów.

Aktualizacja dawnego tekstu kultury polega zatem na włączeniu go w dyskurs XX w. dzięki wypełnieniu nowymi znaczeniami. Jeden $\mathrm{z}$ przykładów to Mannowska reinterpretacja kategorii grzechu i winy. W pierwowzorze Hartmanna pojęcia te mają znaczenie teologiczne i zgodne $\mathrm{z}$ ówczesnym prawem kościelnym: grzech popełniony nawet nieświadomie jest zawsze grzechem, dziecko zrodzone ze związku kazirodczego jest obarczone winą (defectus natalium) i wykluczone ze społeczeństwa ${ }^{34}$. Głównym grzechem wobec Boga, jakiego dopuszczają się zarówno Gregorius, jak i jego rodzice, jest narcyzm i pycha, niezdolność pokochania kogoś innego niż osoba spokrewniona, a więc do nas podobna. Natomiast u Manna problem winy ma raczej wymiar humanistyczny. Kazirodztwo to rodzaj atawizmu, powrót do stanu „naturalnego”, mitycznego, przezwyciężonego przez „ludzkiego ducha” w rozwoju cywilizacyjnym. Grzech polega na poddaniu się irracjonalnym siłom podświadomości i mitu, na zignorowaniu ostrzegawczego głosu „ducha” ${ }^{35}$. Przyczyny występku rodzeństwa, Sybilli i Wiligisa, mają też u Manna inny charakter niżu Hartmanna, który upatruje ich w podszeptach diabła. W Wybrańcu grzech wynika ze splotu okoliczności interpretowanych w duchu freudowskim: kompleks Edypa, wykluczenie brata z bliskiej relacji ojca i córki, chęć wyzwolenia się spod dominacji

${ }^{2}$ J.W. Goethe, Noten und Abhandlungen zu besserem Verständnis des , West-Östlichen Divans”, w: idem, West-Östlicher Divan, Frankfurt am Main 1988, s. 261. Thum - K.L.

33 Czytając w ramach studiów źródłowych nad Gregoriusem historię literatury niemieckiej Wilhelma Scherera (Geschichte der deutschen Litteratur z roku 1883), Mann zwrócił uwagę na wzmiankę, iż wszyscy średniowieczni epicy niemieccy korzystali z obcych wzorów, thumacząc eposy francuskie. Autor Wybrańca zdaje się mieć świadomość, iż sam powtarza pewien wzorzec postawy twórczej, a ze swą intencją parodystyczną we wspomnianym znaczeniu wpisuje się w tradycję thumaczy parodystów w rozumieniu Goethego (zob. G. Wilhelm, Sprachimitation in Thomas Manns Roman „Der Erwäblte”, München 1961, s. 5).

34 Por. U. Beer, Das Gregorius-Motiv. Hartmanns von Aue „Gregorius” und seine Rezeption bei Thomas Mann, Meldorf 2002, s. 30-31.

35 Por. K. Stackmann, op.cit., s. 71. 
ojca $^{36}$. Mann sprowadza motywację czynu do walki indywiduum $\mathrm{z}$ wewnętrznym przymusem i potrzebami - postępowaniem rodzeństwa nie kieruje żadna zewnętrzna nadprzyrodzona siła.

\section{Wyobraźnia poetycka Manna: montaż i ekfraza}

Wybraniec zawdzięcza swój status intertekstualny oraz interdyskursywny nie tylko nawiązaniom do średniowiecznego Gregoriusa i prądów intelektualnych XX stulecia. Jest także wyrazem polemiki z tradycyjną powieścią historyczną. Wniosek taki nasuwa konstrukcja świata przedstawionego, utrzymująca czytelnika w ciągłej niepewności co do relacji między prawdą a fikcją.

Wybraniec na pewno nie jest powieścią historyczną. Przeczy temu nie tyle nawet fikcyjność głównego bohatera, którego nie sposób identyfikować z żadnym $\mathrm{z}$ historycznych świętych ani papieży, ile raczej paradoksalny brak osadzenia akcji w konkretnym czasie. Szczegółowo nakreślone tło społeczno-obyczajowe historii Sybilli i Wiligisa sugeruje dojrzałe średniowiecze (XII-XIII w.), tymczasem opowieść o pontyfikacie Grzegorza, mimo braku jednoznacznej informacji chronologicznej, cofa akcję do $\mathrm{V}$ i VI w. 37. „Syntetyczne” średniowiecze, wewnętrznie niezróżnicowane, jawi się w powieści jako epoka mityczna, symboliczna. Rezygnacja z umiejscowienia akcji w czasie zdradza lekceważenie narratora wobec historyczności: pieczołowicie zebrane szczegóły historyczne mogą w każdej chwili ulec ironicznej relatywizacji ${ }^{8}$. Ustami narratora, mnicha Klemensa, Mann uprzedza i wielokrotnie przypomina o pozaczasowości oraz ahistoryczności opowieści, uświadamia odbiorcy fikcję literacką i tematyzuje proces narracji:

[...] wprawdzie opatrzyłem go [rękopis - K.L.] podaniem miejsca, gdzie siedzę (mianowicie u św. Galla przy pulpicie Notkera), nie powiedziałem był jednak, o jakiej godzinie, w którym roku i wieku po Narodzeniu Zbawiciela naszego tu siedzę [...]. Nie ma tu żad-

${ }^{36}$ Por. D. Lund, K. Jankowsky, K. Thompson, Mittelalterliche Legende im 20. Jabrbundert. Hartmann von Aue und Thomas Manns Gregorius, w: Das Weiterleben des Mittelalters in der deutschen Literatur, red. J.F. Poag, G. Scholz-Williams, Königstein im Taunus, 1983, s. 174.

37 Przykładowo - scena tryumfalnego wjazdu Gregoriusa jako nowego papieża do Rzymu wzorowana jest na opisach trzech podobnych epizodów historycznych z różnych okresów; źródłem była tu Historia miasta Rzymu w średniowieczu Ferdinanda Gregoroviusa (por. H. Weigand, op.cit., s. 30).

$3^{8}$ Por. K. Stackmann, op.cit., s. 65. 
nego punktu zaczepienia, nie jest nim także imię naszego opata Gozberta ${ }^{39}$.

Za sprawą narratora o dwoistym statusie (jako konkretnej postaci, wyposażonej $\mathrm{w}$ życiorys, a nawet cechy charakteru ${ }^{40}$, i jako abstrakcyjnego „ducha opowieści”) Mann buduje ironiczny dystans do prawdy historycznej, a jednocześnie prowadzi $\mathrm{z}$ czytelnikiem grę $\mathrm{w}$ historyczność. Paradoks powieści polega bowiem na tym, iż nieustanne zastrzeżenia o „bezczasowości” relacjonowanych zdarzeń przeplatają się z usilnymi staraniami, by stworzyć złudzenie autentyczności. Przykładowo, Mann wplata w życiorys Gregoriusa fakty znane $\mathrm{z}$ biografii kilku różnych papieży (m.in. Grzegorza I, Leona I czy Feliksa II), a także świętego Augustyna ${ }^{4 \mathrm{I}}$ - po to, aby uwiarygodnić niesamowite koleje losu bohatera i zasugerować jego prawdziwość. Liczne nazwy miejscowe pojawiające się w toku akcji odnoszą się do miejsc i krain historycznych (Bruges, Flandria, Artois, Akwitania, Rzym, Burgundia i Arelat) i dopiero bezskuteczne poszukiwanie na mapie uświadamia czytelnikowi, że pośród nich występuje wiele nazw (i miejsc) stanowiących fikcję literacką - choćby wyspa Sankt Dunstan, na której dorasta Gregorius.

Iluzję autentyczności, raz po raz podważaną, autor Wybrańca osiąga dzięki kronikarskiej dokładności w opisie realiów epoki czy to dojrzałego średniowiecza, czy to Rzymu u schyłku antyku. Nagromadzenie imion własnych, nazw potraw, napojów, części odzieży, broni itp. nie jest jednak wytworem poetyckiej fantazji pisarza, lecz rezultatem montażu i ekfrazy.

Dzięki zachowanemu archiwum Manna wiemy, że pisarz czerpał z wielu źródeł, choć czytał je wybiórczo i dość pobieżnie ${ }^{42}$. Autor Buddenbrooków uzupełniał swą (raczej skąpą) wiedzę o średniowiecznej literaturze na podstawie Geschichte der deutschen Litteratur Wilhelma Scherera. Epos Wolframa von Eschenbacha Parzival okazał się istną kopalnią słownictwa i opisów z dziedziny

39 T. Mann, Wybraniec, thum. A.M. Linke, Warszawa 1988, s. 12. Kolejne cytaty z tego wydania oznaczam w tekście skrótem W, za którym podaję numer strony.

$4^{\circ}$ Również sam Klemens jako postać w powieści jest konstrukcją ahistoryczną: pewne szczegóły jego biografii, jak wykształcenie odebrane w klasztorze, odsyłają do wczesnego średniowiecza, jednak miejscami jest on wręcz stylizowany na Erazma z Rotterdamu (por. H. Weigand, op.cit., s. 84).

${ }^{4}$ Jak sam pisze, ,zrzucił [Gregoriusowi] na głowę wszelkie możliwe zasługi historycznych papieży” (T. Mann, Selbstkommentare: „Der Erwäblte”. Informationen und Materialien zur Literatur, red. H. Wysling, M. Eich-Fischer, Frankfurt am Main 1989, s. 36).

$4^{2}$ Praca przygotowawcza do Wybrańca zajęła mu nie więcej niż kilka tygodni (por. H. Wysling, op.cit., s. 157). 
obyczajów rycerskich i życia codziennego na dworze książęcym $^{43}$. Informacje o średniowiecznym myślistwie pisarz czerpał z Tristana, którego autorem był Gottfried von Strasburg, opisy oręża i pojedynków - z Pieśni o Nibelungach. Z Mimesis Ericha Auerbacha przejął wtrącenia w języku starofrancuskim ${ }^{44}$, natomiast epizody $\mathrm{z}$ historii papiestwa i opis Rzymu w końcowych rozdziałach powieści są oparte na monumentalnej Geschichte der Stadt Rom im Mittelalter Ferdinanda Gregoroviusa (Historii miasta Rzymu w'średniowieczu, 1859-1872)45. Jak wykazano, cytaty z obcych tekstów - średniowiecznych zabytków literatury, ale też XIX- oraz XX-wiecznych leksykonów fachowych i popularnych - stanowią $\mathrm{w}$ niektórych partiach powieści nawet siedemdziesiąt procent tekstu ${ }^{46}$. Dla pisarza nie był istotny ani czas powstania danego hipotekstu, ani jego ranga, ani gatunek; do swojej „układanki” wybierał te fragmenty, z których mógł złożyć możliwie barwny obraz średniowiecza.

Inne ważne źródło inspiracji Manna stanowiła ikonografia dawna i współczesna. Wiele opisów postaci i realiów epoki w Wybrańcu opiera się na autentycznych wizerunkach. Najlepszy przykład to powieściowy obraz księżniczki Sybilli, który można określić mianem ekfrazy: opis sylwetki, sukni, fryzury i biżuterii bohaterki wzorowany jest na anonimowym XV-wiecznym płótnie Ulmer Verlöbnis (Zaręczyny w Ulm) ${ }^{47}$. Teczki Manna z materiałami gromadzonymi do Wybrańca zawierają także wycięte $\mathrm{z}$ gazet zdjęcia przedstawiające krajobrazy, sceny z życia rybaków i pasterzy - najwyraźniej inspiracje dla twórcy scenerii epizodów z wyspy Sankt Dunstan. Jest tam także fotografia młodzieńca, podpisana przez Manna imieniem Grigorss - opisując wygląd swego bohatera, autor musiał mieć przed oczyma to właśnie zdjęcie ${ }^{48}$.

Wgląd w archiwum pisarza pokazuje, że wyobraźnia twórcza niemieckiego noblisty szczególnie mocno wiązała się z percepcją

43 Pochodzi stąd blisko czterdzieści imion własnych, nazw krain, miast, zamków - por. H. Weigand, op.cit., s. 14.

44 Chodzi o dialog Sybilli i Wiligisa w rozdziale Niedobre dzieci, wzorowany na cytowanym przez Auerbacha fragmencie XII-wiecznego intermedium bożonarodzeniowego Mystère d'Adam (zob. E. Auerbach, Adam $i$ Ewa, w: idem, Mimesis. Rzeczyrwistość przedstawiona w literaturze Zachodu, thum., wstęp Z. Żabicki, t. 1, Warszawa 1968, s. 252-255).

45 Por. np. H. Wysling, op.cit., s. 157. Dokładnej rekonstrukcji wykorzystanych w Wybrańcuźródeł dokonał Weigand, uzupełnił ją - już po śmierci Manna, na podstawie jego archiwum - Hans Wysling.

${ }^{46}$ Por. H. Wysling, op.cit., s. 172.

47 Pisarz oglądał ten obraz w muzeum w amerykańskim Cleveland, a w swoim gabinecie powiesił jego reprodukcję (zob. ibidem, s. 173).

$4^{8}$ Por. ibidem, s. 174. 
wzrokową ${ }^{49}$. Taka dyspozycja psychologiczna Manna predestynowała go do transpozycji oglądanych obrazów na język werbalny - ekfrazy.

\section{Zamiast palimpsestu: baśniowość, archaizacja i wyobraźnia tłumaczki}

Ekfraza i montaż hipotekstów, umożliwiające w Wybrańcu wypełnienie schematu fabularnego realiami, uruchamiają zasoby pamięci kulturowej. W jakim stopniu zabieg ten jest widoczny w tłumaczeniu polskim? Jako przykład posłuży wspomniany już opis Sybilli, ubranej odświętnie z okazji turnieju rycerskiego jej brata Wiligisa:

Wollt ihr wissen, wie das Fräulein zur Feier des Tages gekleidet war, so war sie angetan mit einem Kleide, so grün wie Gras, aus Assagauker Sammet, schön weit und lang und luxuriös gerafft, und wo es vorn in breiten Falten gerafft war, sah man, daß das Futter aus roter und das Unterkleid aus weißer Seide war. An ihrem elfenbeinfarbenen Halse schloß es rund und war, wie an den Handgelenken, mit Perlen und Steinen gesäumt, die tiefer auf der Brust zu einem breiten Geschmeide zusammentraten. Dicht besetzt mit Edelsteinen war auch ihr Gürtel, und der Jungfrauenkranz in ihrem offenen Haar, er ebenfalls, bestand aus kleinen Rubinen und Granatsteinen grün und $\operatorname{rot}^{50}$.

Pewnie chcecie wiedzieć, jak była panna w ten uroczysty dzień ubrana: otóż stroiła ją szata zielona jak trawa, $\mathrm{z}$ assagajskiego aksamitu, piękna, luźna i długa, przepysznie się drapująca; a z przodu, gdzie tworzyła szerokie fałdy, widać było, że podszycie jest z czerwonego, spodnia zaś suknia z białego jedwabiu. Zakończona krągło pod jasną jak kość słoniowa szyją Sybilli, obszyta była u przegubów rąk perłami i drogimi kamieniami, które także na piersiach tworzyły szeroki ornament. Również jej pasek był gęsto wysadzany szlachetnymi kamieniami, a i wianuszek panieński na rozpuszczonych włosach składał się z drobnych rubinów i zielonych oraz czerwonych granatów. (W, s. 21)

49 Co ma zresztą uzasadnienie psychologiczne: neurolodzy i psycholodzy zgodnie dziś twierdzą, że „neuroanatomiczne szlaki wzrokowe, które są odpowiedzialne za percepcję wizualną, są także intensywnie wykorzystywane podczas procesów wyobrażeniowych" (P. Francuz, op.cit., s. 11-12).

$5^{\circ}$ T. Mann, Der Erwäblte, w: idem, Bekenntnisse des Hocbstaplers Felix Krull. Der Erwäblte, Berlin - Weimar 1975, s. 434. Kolejne cytaty z tego wydania oznaczam w tekście skrótem DE, za którym podaję numer strony. 
U Manna opis ten łączy w sobie ekfrazę (opis autentycznego obrazu) i montaż: podobny fragment znajduje się w Parzivalu (wzmianka o ośmiu dziewicach usługujących przy stole na zamku Graala) ${ }^{51}$. Czytelnik bez specjalistycznego przygotowania nie rozpozna w Mannowskim oryginale ani nawiązania do wizerunku narzeczonych z Ulm, ani do Parzivala, lecz mglistą reminiscencję eposów średniowiecznych ${ }^{52}$. Z kolei przekład polski przywołuje bardziej atmosferę baśniowości niż konkretnych wzorców literackich. Zarówno tekst Tomasza Manna, jak i Anny Linke uaktywnia natomiast wyobraźnię odbiorcy, odsyłając go do poetyki malarstwa średniowiecznego - ikonicznych zasobów pamięci kulturowej. Pamięć tę ukształtowali głównie artyści z Europy Północnej: holenderscy i niemieccy portreciści oraz twórcy dzieł religijnych ${ }^{53}$, niejednokrotnie umieszczający motywy sakralne w scenerii najzupełniej świeckiej ${ }^{4}$.

Zacytowany fragment przywołuje charakterystyczną dla sztuki średniowiecznej kolorystykę i związaną z nią symbolikę barw, szczególnie wyraźną w malarstwie ołtarzowym i miniaturowym, witrażach i mozaikach, a także realistyczną drobiazgowość w oddawaniu szczegółów, jaką znamy z dzieł Rogiera van der Weydena, Jana van Eycka czy Hansa Memlinga55. Wspomniane w opisie perły, kolor kości słoniowej i mieniące się drogie kamienie - to aluzja do estetyki średniowiecza, utożsamiającej piękno z blaskiem ${ }^{56}$; wzmianka o jedwabiu i ,assagajskim aksamicie” również „odsyła” do ówczesnego przekonania,

${ }^{51}$ Gwoli ścisłości - Mann nie wzorował się bezpośrednio na tekście Wolframa, ale na dostępnym mu thumaczeniu Wilhelma Hertza z roku 1897. Świadczy o tym także fakt, że pisownia wielu imion własnych przejętych przez Manna z Parzivala odpowiada transkrypcji tekstu średniowysokoniemieckiego, którą zastosował Hertz (por. H. Weigand, op.cit., s. 14). Tłumaczenie Hertza brzmi: „Ein Kleid, noch grüner als das Gras/ Trug von den acht jedwede Maid;/ Von Samt von Assagauk war das/ Zierlich geschnitten, lang und weit, / und um die Hüfte fest sich schlang/ ein teurer Gürtel, schmal und lang, / ein jedes von den Fräulein klar/ trug einen kleinen Kranz im Haar/ aus duft'gen Blüten, bunt und hell” (cyt. za: H. Wysling, op.cit., s. 173).

${ }^{2}$ Tym bardziej że dziś Parzivala czyta się w nowym przekładzie prozą (zob. W. von Eschenbach, Parzival. Mittelhochdeutsch/Neubochdeutsch, thum., posłowie W. Spiewok, Stuttgart 1989).

53 Jak pisze Johan Huizinga, malarstwo późnego średniowiecza „kojarzy nam się dzisiaj od razu z głęboką powagą ołtarza i portretu” (J. Huizinga, Jesień średniowiecza, thum. T. Brzostowski, Warszawa 1992, s. 328).

54 O przenikaniu się przestrzeni sakralnej i świeckiej w malarstwie średniowiecznym - zob. B. Uspienski, Kompozycja Ottarza Gandawskiego Jana van Eycka wświetle semiotyki (Boska i ludzka perspektywa), w: Sztuka w świecie znaków, red. B. Żyłko, Gdańsk 2002.

55 O metodzie twórczej średniowiecznych malarzy „polegającej na nieograniczonym wypracowywaniu szczegółów" - por. J. Huizinga, op.cit., s. 330.

${ }_{56}^{6}$ Por. ibidem, s. 317. 
że kosztowny, wspaniały materiał jest wyrazem hołdu, jaki artysta składa Bogu 57 . Kolory wymienione w literackim portrecie Sybilli: biel oraz czysta, nasycona, chromatyczna zieleń połączona z czerwienią są - obok błękitu i złota - najważniejszymi barwami średniowiecznych malowideł, fresków i witraży, niosące ze sobą bogatą symbolikę ${ }^{8}$. Również drogie kamienie - jak opisane przez Manna rubiny i granaty - uważano za najpiękniejsze wcielenie danej barwy 59 .

Mannowski oryginał uruchamia u czytelnika niemieckiego kulturową pamięć literatury $\mathrm{w}$ miejscach stylistycznie nawiązujących do eposów średniowiecznych. Jeden z bohaterów, opowiadając o walecznych czynach Gregoriusa, w mimowolnej rytmizacji, rymach i starogermańskich aliteracjach naśladuje styl eposów rycerskich:

Den Fisch auf seinem Schilde, so schwang er bar und hell sein Schwert, das war ihm, zwiegeschliffen, der einzige Gesell. Da kamen sie gelaufen von Herzog Rogers Lehn, weil sie seiner Waffe Winken und das offene Tor gesehn. Des wollten sie Nutzen nehmen, den einen bald abtun; doch wie er sich ihnen verleidet, das sollt ihr hören nun. Wie ist mir, ich will gar nicht reimen - und lügen, doch, der Daus! Ich glaube, ich find aus dem Märentakt mein Lebtag nicht heraus. Gregorius vom Fische, schnell war er genug! Von Rogers Heergesinde er drei behend erschlug. Er schlug sie durch die Helme mit schwindem Schwertesschlag. Zwei rollten in den Graben, der dritte vor ihm lag. Zum üblen Teufel, Truchseß, [...] ich nehme mich zusammen und singe nicht [podkr. - K.L]. (DE, s. 539-540)

Kroczy z mieczem - swym druhem, na tarczy - ryby znak. Miecz nagi obosieczny jasno błyska mu w takt. Widząc, jak bronią macha i bramę sobie otwiera, nadbiegają wnet ludzie z obozu króla Rogera. Chcieli skorzystać zaraz, jednego na miejscu ubić, a ten im zadał bobu, że jest się czym pochlubić! - Cóż mi to? Nie chcę rymować ni łgać, - a tu ani rusz: z rytmu klechdy rycerskiej snadź nie wygrzebię się już! A Gregor herbu Ryba w lot sobie z nimi radzi: porąbał

57 Por. M. Rzepińska, Splendor sztuki średniowiecza, w: eadem, Historia koloru w dziejach malarstwa europejskiego, Warszawa 1989. Autorka wskazuje na pewne właściwości kolorystyczne malarstwa średniowiecznego, które nietrudno rozpoznać w literackim obrazie Manna: między innymi płaszczyznową, nie zaś przestrzenną organizację barwy, jej użycie w czystej postaci, bez stopniowania intensywności i bez światłocienia, dążenie do kolorystycznej symetrii oraz „wyraźne granice między strefami barwnymi, wzmagające jeszcze ich kontrastowość" (ibidem, s. 145).

$5^{8}$ Por. ibidem, s. 128-136.

59 Por. ibidem, s. 126. 
aż trzech zuchów z Rogerowej czeladzi! Rozpłatał ich skroś hełmy, piorunowymi ciosy, jeden legł mu pod stopy, dwu spadło do fosy... Tam do diabła starego, stolniku, [...] biorę się w garść, przestaję śpiewać. (W, s. 119)

W tłumaczeniu rytmizowana proza pozbawiona jest motywacji. W polskiej tradycji literackiej epos rycerski nie jest rozpoznawalny tak, jak w kręgu niemieckojęzycznym. Gatunek ten kojarzymy z Pieśnia o Rolandzie albo ze Stowem o wyprawie Igora, które notabene same są przekładami. „Klechda rycerska” nie oznacza specyficznego gatunku, stąd Mannowskie nawiązania w przekładzie stają się nieczytelne.

Dostrzegalne sygnały pamięci kulturowej kryją się w nazwach własnych, w których czytelnik niemiecki bezbłędnie rozpozna zapożyczenia z Parzivala. Imiona bohaterów Wolframa pojawiają się we fragmencie mówiącym o licznych konkurentach do ręki księżniczki Sybilli:

$[\mathrm{E}] \mathrm{s}$ mehrten sich die Werbungen um ihre Hand von stolzen Fürsten der Kristenheit, die sich des Antrags wohl getrauen durften. Teils schrieben sie, teils schickten sie edle Freiwerber nach Belrapeire, teils kamen sie auch selbst zur Freite dorthin: Der alte König von Anschouwe brachte seinen Sohn Schafillor, der freilich ein Depp war. Graf Schiolarß von Ipotente, der Gaskonen Herzog Obilot, Plihopliheri, Fürst von Waleis, sowie die Herren von Hennegau und Haspengau [...]. (DE, s. 440)

Jęly się tedy mnożyć konkury do jej ręki od dumnych książąt chrześcijaństwa, co mogli się snadnie pokusić o deklarację. Jedni pisali, drudzy wysyłali do Belrapeire godnych dziewosłębów, inni jeszcze sami przybywali w zaloty; stary król Anchouve przywiózł swego syna Szafilora, który był, co prawda, głuptakiem. Przybyli: graf Żiolars z Ipotente, książę Gaskończyków Obilot, Plihopliheri, książę waloński, jako też panowie: von Hennegau i Haspengau [...]. (W, s. 26-27)

W oryginale już samo hasło Belrapeire (zamek księcia Grimalda) odsyła do nazwy miasta rządzonego przez królową Kondwiramurs - małżonkę Parzivala. Referencji tych raczej nie można odtworzyć w przekładzie - a w każdym razie mało prawdopodobne wydaje się, że zrozumiałby je polski czytelnik. Co zatem proponuje tłumaczka w miejsce Mannowskiego palimpsestu apelującego do pamięci kulturowej niemieckiego odbiorcy?

Pomocne okazują się baśniowość i archaizacja językowa, a także własna wyobraźnia tłumaczki, podsuwająca intuicyjne 
konkretyzacje miejsc u Manna niejasnych. W przekładzie imiona, zapisane zgodnie $\mathrm{z}$ fonetyką polską, sprawiają wrażenie imion fantastycznych, takich, jakie noszą bohaterowie baśni. Atmosferę baśniowości i zamierzchłych czasów (sygnalizowaną w poprzednim cytowanym fragmencie zwrotem „klechda rycerska”) podkreślają liczne archaizmy leksykalne (dziewosłęby, snadnie, tedy, jako też) i morfologiczne (w poprzednim fragmencie: skroś hełmy, piorunowymi ciosy). Zabieg archaizacji wymuszony został przez sam oryginał utkany ze słów, które Mann zaczerpną z tekstów średniowiecznych. Z drugiej strony tłumaczka nawiązuje do bogatej tradycji polskich powieści historycznych, wskrzeszających dawną polszczyznę. W odróżnieniu od Manna, który miał do dyspozycji przebogatą literaturę XII w., Linke nie mogła sięgać do tak odległych źródeł, bo tych w polskim piśmiennictwie brak: archaizacja u Sienkiewicza, Kraszewskiego czy Gołubiewa opiera się na języku dużo późniejszym ${ }^{60}$. Efekt zabiegów stylizacyjnych tłumaczki należałoby więc przypisać wnikliwej lekturze polskich powieści historycznych, których echa pobrzmiewają też we fragmencie o pojedynku Gregora: rycerz, który „porąbał aż trzech zuchów z Rogerowej czeladzi”, mógłby się pojawić na kartach Sienkiewiczowskiej Trylogii...

Użyte w Wybrańcu archaizmy, których niepodobna znaleźć we współczesnych słownikach (np. Marner, Ellender, Holmgang, Urliuge), autorka przekładu rozszyfrowuje na ogół trafnie. W ich miejsce proponuje wyrażenia podniosłe, sygnalizujące dawność:

Hast du wohl Augen gehabt für Alisse von Poitou [...]? Es fanden sie viele so wätlich. - Ich habe keine Augen gehabt für ihre prätendierte Wätlichkeit. (DE, s. 436)

Czyś zwracał oczy ku Alisse de Poitou [...]? Wielu mniemało ją tak nadobną. - Nie zwracałem oczu ku tej rzekomej krasie. (W, s. 23; fragment dialogu Sybilli i Wiligisa; wätlich - piękny - to słowo używane w eposach średniowysokoniemieckich, później wyszło z użycia $\left.{ }^{6 \mathrm{~T}}\right)$.

Also soll ich aus diesem Wurmgarten scheiden, [...] während ihr noch ein lützel in diesem Wurmgarten verharren müßt. (DE, s. 441-442) s. 142.

6o Por. B. Chrząstowska, S. Wysłouch, Poetyka stosowana, Warszawa 2000,

6I Por. G. Wilhelm, op.cit., s. 30-31. 
Mam tedy opuścić ten padół robactwa, [...] podczas gdy wy pozostać jeszcze krzynę musicie na tym padole. (W, s. 28; słowa umierającego księcia Grimalda do wasali zgromadzonych u jego łoża).

Das war gewiß ein guter, gewaerer Mann, ich sah es ihm von den Augen ab, du aber hast nichts als grausame Schmähung und Itewize für ihn gehabt [...]! (DE, s. 595)

Był on na pewno dobrym, zacnym człowiekiem, z oczu mu to patrzyło; a ty miałeś dla niego jeno okrutną zelżywość i urągania [...]! (W, s.171; tak mówi żona rybaka, wyrzucając swemu mężowi, że źle potraktował Gregoriusa - wędrowca, odmawiając mu gościny pod swym dachem; średniowysokoniemieckie Itewize - obelga, obraza ${ }^{62}$, przymiotnik gewaere - dobry, wierny, solidny, uczciwy ${ }^{6} 3$ ).

Niektórych archaizmów tłumaczka nie rozumie i musi polegać na własnej wyobraźni. Stąd wyrazy przełożone błędnie, które nie odbierają polskiemu tekstowi walorów estetycznych ani wiarygodności, ponieważ pasują do obrazu realiów epoki, jaki może wyobrazić sobie czytelnik:

Der Junker dagegen hatte einen Gurneval, mit Namen Herr Eisengrein, Cons du chatel, will sagen einer festen Wasserburg mit Gräben breit und tief und einem Berchfrit, der weit ausschaute übers Meer [...]. (DE, s. 432)

Panicz natomiast miał guwernera nazwiskiem pan Eisengrein, cons du châtel, chcę powiedzieć zamczyska o fosach szerokich i głębokich, ze stromym wzgórzem spoglądającym daleko w morze [...]. (W, s. 19)

Berchfrit (w innej pisowni: Bergfried) to wieża obronna w zamku ${ }^{64}$. Jednak „strome wzgórze”, wymyślone tu przez tłumaczkę, doskonale pasuje do obrazu warownego zamczyska, jaki znamy z zabytków architektury i z ikonografii. Wystarczy przypomnieć choćby misternie oddane sylwetki zamków francuskich z modlitewnika braci Limburg (znanego jako Bardzo bogate godzinki księcia de Berry), widoczne w tle miniatur przedstawiających poszczególne miesiące roku ${ }^{65}$.

${ }^{62}$ Por. ibidem, s. 74.

${ }_{63}$ Por. ibidem, s. 58.

${ }^{64} \mathrm{~W}$ tym znaczeniu występuje w Parzivalu - por. ibidem, s. 49.

65 Johan Huizinga tak pisze o owych realistycznych miniaturach: „Na obrazie przedstawiającym wrzesień, w głębi za sceną winobrania, wznosi się jak we śnie 
[Im Schlafgemach von Sybilla und Willigis, ] wo ihre Spannbetten standen, mit Gurten aus Salamanderfell, auf denen die Kissen lagen, und Stollen von Vipernschlangen. Das Polster unter den Kissen war Palmat. (DE, s. 430)

[W sypialni Sybilli i Willigisa] stały ich rozpięte na ramach łoża, o pasach ze skóry salamandry, na których leżały poduszki, oraz podpórkach kręconych na kształt wężów. Wyściółka pod poduszkami była z palmowych włókien. (W, s. 18)

Mimo podobieństwa fonetycznego Palmat nie oznacza liści palmowych, tylko kosztowny jedwab tkany w średniowieczu w mieście Palma na Balearach ${ }^{66}$. A jednak liście palmowe, kojarzące się z egzotycznymi, trudno dostępnymi dobrami, doskonale oddają atmosferę luksusu, w jakiej wzrastają bohaterowie powieści.

Również inne słowa opisujące zbytkowne przedmioty w zamku księcia Grimalda nie zawsze oddane są zgodnie z ich historycznym znaczeniem. Przykładowo: Stüble mit Polstern von arabischem Achmardi (DE, s. 425) to w przekładzie fotele wyściełane „arabskimi dywanami” (W, s.13) - chociaż według niektórych źródeł Achmardi oznaczał barwioną na zielono skórę ${ }^{67}$. Pierwotne znaczenie tego słowa nie jest całkiem jasne, dlatego przypuszcza się, że Mann - sam niepewny, o jaki materiał chodzi - użył go, nie troszcząc się zbytnio o jego referencję, lecz ze względu na konotacje z egzotyką, bogactwem i wystawnością. Podobne wrażenie sprawiają na czytelniku polskim wymyślone przez tłumaczkę „arabskie dywany” - nawiązanie do ponadczasowej, baśniowej atmosfery królewskiego dworu.

\section{Wyobraźnia językowa: fikcyjny dialekt w oryginale i przekładzie}

W przypadku realiów oraz archaizmów tłumaczce nietrudno dzięki własnej wyobraźni, korzystającej z wizualnego i literac-

zamek Saumur: czubki wież z wyniosłymi chorągiewkami, strzeliste wieżyczki gotyckie, na blankach ornament $\mathrm{z}$ lilii [...]. Obok tego wspomnijmy także majestatyczną powagę książęcego zamku Lusignan na karcie marcowej i ponure wieże Vincennes, które wznoszą się groźnie ponad suchymi drzewami grudniowego lasu” (J. Huizinga, op.cit., s. 345). Można powiedzieć, że opis ten odnosi się do „prototypowego" średniowiecznego zamku - takiego, jaki wyłania się również $\mathrm{z}$ thumaczenia powieści Manna.

${ }^{66}$ Por. G. Wilhelm, op.cit., s. 18.

${ }_{7}$ Por. ibidem, s. 19. 
kiego archiwum pamięci kulturowej, stworzyć przekład adekwatny stylistycznie. Niekiedy jednak ani wyobraźnia, ani pamięć kulturowa nie mogą przyjść jej z pomocą. Chodzi o te fragmenty, w których Mann stosuje stylizację na wyimaginowany dialekt. Konstruując fikcyjną mowę rybaków z wyspy Sankt Dunstan, posiłkuje się językiem Plattdeutsch i angielskim, a nawet żargonem amerykańskich reportaży sportowych ${ }^{68}$. Ów fikcyjny dialekt prostych wieśniaków kontrastuje $\mathrm{z}$ wykwintną niemczyzną uczonego opata ${ }^{69}$. Widać to wyraźnie $\mathrm{w}$ dialogu duchownego $\mathrm{z}$ rybakami powracającymi z nieudanego połowu:

„Hallo, hoihe, ihr Wackeren, Wiglaf und Ethelwulf, willkommen am Lande, im sicheren Port! Daß ihr nur wieder zurück seid aus diesem Wetter, dafür sei Gott gepriesen! Wir täten am besten, alle drei auf der Stelle niederzuknien und Ihm Lob zu singen. Ihr sehr wohl, euer Abbot hat sich bitter um euch gesorgt, daß er zum Strande gewallt ist durch Sturm und Regen. Wie geht es euch? Habt ihr Fische?" „Heho, hallo, Herr, is noch mal gutgegangen”, erwiderten sie. „Fische? Nee, dat's nu'n littel bit tau veel verlangt. Wi könn von Lucke seggen, dat uns de Fisch nich hebben, denn dat was Euch 'ne Freise, Herr, un weren Euch coups de vent, da macht Ihr Euch, Herr, gar keen Einbildung von. Da mußt immer een Mann die Seen drawen aus dem Boot un de annere mit all sin Macht den Timon holden, un sonst was an keen Ding ein Denken an".

„Wie sie reden”, dachte der Abt. „Höchst ordinär”. (DE, s. 483)

- Halo, hoihe, o, dzielni Wiglafie i Ethelwulfie! Witajcie na lądzie, w bezpiecznej przystani! Bogu niech będzie chwała, żeście powrócili z takiej burzy! Najlepiej byśmy uczynili klękając tu wszyscy trzej, na miejscu, by Go pochwalić śpiewem. Widzicie, jak wasz opat gorzko się o was martwil, skoro przywędrował na brzeg w deszcz i burzę. Jak się czujecie? A macie ryby?

- Heho, halo, panie, tym razem się udało - odrzekli. - Ryby? Co to, to nie, tobyście już little bit za dużo chcieli! Można gadać o szczęściu, że ryby nas nie mają, bo to ci był dopiero sztorm, to ci były coups de vent, wcale sobie tego, panie, nie możecie wystawić! Zawsze jeden

${ }_{68}$ Por. ibidem, s. 91-92.

${ }^{69}$ Zakwalifikowanie dialektu wykorzystującego elementy angielskie jako ordynarnego mogło mieć przyczyny biograficzne: Mann uważał mieszankę niemiecko-angielską, z jaką stykał się na emigracji w USA, za język ,zachwaszczony", zniekształcony (por. G. Wilhelm, op.cit., s. 111). Stylizacja w Wybrańcu miała być ukrytą refleksją nad niepokojącą łatwością interferencji i postępującą degradacją ojczystego języka w środowisku emigrantów (por. H. Weigand, op.cit., s. 92). 
musiał wylewać morze z łodzi, a drugi z całej mocy trzymać ster; kto by tam myślał o czym innym!

„Jakże oni gadają - pomyślał opat; - zgoła nieokrzesanie!” (W, s. 67)

Ponieważ wyspa Sankt Dunstan na wyimaginowanej mapie kanału La Manche to miejsce o charakterze interkulturowym, ponadczasowym i pozajęzykowym, nie dziwią wtrącenia angielskie (littel bit) czy francuskie (coups de vent). Dziwaczne formy językowe uderzają czytelnika swą obcością, dlatego odczucia opata, określającego mowę swoich rozmówców jako ordynarną (ordinär), są zrozumiałe. W polskim przekładzie brak jakiegokolwiek kontrastu między idiolektem uczonego mnicha a dialektem rybaków. Przejęte z oryginału sformułowania obcojęzyczne - angielskie, a zwłaszcza francuskie - wywołują efekt odwrotny od zamierzonego w pierwowzorze, wręcz groteskowy: świat przedstawiony w thumaczeniu Anny Linke to wprawdzie nadal pogranicze angielsko-francusko-germańskie, ale przecież bohaterowie mówią po polsku! Odbiorcy przekładu raczej trudno sobie wyobrazić, jakoby prości ludzie w języku polskim przeplatali swe wypowiedzi zwrotami obcojęzycznymi. Szczególnie francuszczyzna ma w naszym kręgu kulturowym status języka elitarnego, świadczącego o wykształceniu i wytwornym wychowaniu. W tym kontekście zgorszenie opata, iż jego interlokutorzy wysławiają się „zgoła nieokrzesanie”, jest niezrozumiałe i nieuzasadnione, gdyż stoi w sprzeczności z faktycznym rejestrem stylistycznym ich wypowiedzi.

Wobec tak specyficznego ukształtowania warstwy językowej oryginału tłumaczka okazała się bezradna; wyobraźnia językowa najwyraźniej ją zawiodła. Może w miejsce wyimaginowanego dialektu z Sankt Dunstan należało poszukać jakiejś regionalnej odmiany polszczyzny? A może w tej roli sprawdziłby się język kaszubski - na zasadzie analogii, jako mowa rybaków żyjących na polskim wybrzeżu?

Analiza pokazała, jak tłumaczka prezentuje Mannowską praktykę symboliczną, opartą na przekładzie parodystycznym, montażu i ekfrastycznych nawiązaniach do tekstów kultury. Najprostsze zadanie miała Anna Linke w ostatnim przypadku. Ikonograficzne zasoby pamięci kulturowej, do której sięga Mann, mają charakter ponadnarodowy i ponadjęzykowy - ogólnoeuropejski. Dlatego przekład tak samo skutecznie jak oryginał apeluje do wyobraźni 
czytelnika, uruchamia skojarzenia z poetyką malarstwa średniowiecznego. Trudności translatorskie zaczynają się tam, gdzie pamięć kulturowa zapisana jest w tekstach literackich: archiwum polskojęzycznego odbiorcy nie zawiera odpowiednich wzorców gatunkowych i tekstowych, które rozpoznaje w pierwowzorze czytelnik niemiecki. Tłumaczka ucieka się do ponadczasowej atmosfery baśni oraz poetyki i stylu klasycznej polskiej powieści historycznej - paradoksalnie, akurat tego gatunku, z którym Mann w swoim utworze polemizuje. Największe zaś wyzwanie stanowi fikcyjny dialekt - dzieło wyobraźni językowej autora.

Zarówno przekład, jak i pamięć kulturowa nie mogą istnieć bez wyobraźni. Retrospektywna i reproduktywna zdolność wyobraźni łączy ją z pamięcią, natomiast jej wymiar estetyczny, zdolność konkretyzacji - z przekładem. Rozumienie wyobraźni w duchu freudowskim, jako zdolności twórczej w ogóle ${ }^{70}$, pozwala $\mathrm{w}$ niej widzieć jeden $\mathrm{z}$ fundamentów pamięci kulturowej, ponieważ oryginalny utwór literacki oraz związany z nim intertekstualnie przekład są dziełami wyobraźni artystów, a zarazem mediami i sposobami tworzenia pamięci kulturowej. Zatem nawet jeśli - jak w przypadku Manna - piórem artysty „kieruje nie tyle pomysł, ile stała przytomność umysłu, cierpliwie i uważnie zbierająca materiały, inteligencja, która wprawdzie nie wymyśla nowych przedmiotów, ale stwarza między nimi powiązania" ${ }^{71}$, to do takiej aktywności kulturotwórczej niezbędna jest wyobraźnia, która polega także na kombinacji gotowych elementów. Trzeba podkreślić, że wyobraźnia Manna uwidaczniająca się w wybranej przezeń praktyce symbolicznej „przekładu pamięci” - nie prostej repetycji, lecz transformacji i uaktualniania - jest też zorientowana prospektywnie: pokazuje, co jeszcze w literaturze jest możliwe ${ }^{72}$.

\section{KATARZYNA LUKAS}

\section{Author's and translator's imagination in confrontation with cultural memory. On Thomas Mann's The Holy Sinner and its Polish translation}

On the example of Mann's Der Erwäblte (1951) and its Polish version Wybraniec (1960) by Anna Linke, the article demonstrates how the crea-

$7^{\circ}$ Por. G. Butzer, op.cit., s. 438.

${ }^{71}$ Por. H. Wysling, op.cit., s. 176.

${ }^{2}$ Nawet jeśli sam Tomasz Mann przewidywał, że jest ostatnim pisarzem, który wykorzystuje legendę o świętym Grzegorzu jako literackie tworzywo (por. list do Hermanna J. Weiganda z 5 listopada 1951 r. w: T. Mann, Selbstkommentare, s. 88-89). 
tor's imagination (the creators are the author and the translator) is related to translation and cultural memory, the basic notions of recent German culture studies. Mann's novel can be described as a parodistic translation of a medieval epic, a text belonging to German cultural memory, into 20th century discourse and language. The article shows Mann's translation strategies, whose aim is actualisation of the stocks of cultural memory of German readers: an experimental style imitating Medieval language, specific structure of narration time, represented world, and the narrator's character, the montage and ecphrasis, which are all techniques calling for creative imagination. The article then demonstrates how Mann's techniques were rendered in the translation. The analysis shows that Linke's text, by referring to cultural memory of Polish readers, activates the content which is absent in cultural memory of German readers: this is because the translation employs fabulous and archaic elements derived from Polish historical novel, instead of stylistic and genre-specific techniques of German medieval epics. References to the visual archive of common European cultural memory (medieval iconography and architecture) clearly facilitate the translation, and the translator's own imagination allows for credible rendition of names of medieval realities. The most important task was the rendition of the medieval dialect, which was fully Mann's imaginary creation.

Keywords: cultural memory, archive, Middle Ages, montage, ecphrasis, medieval epic, parodistic translation.

Katarzyna Lukas - doktor, absolwentka germanistyki UAM, adiunkt w Instytucie Filologii Germańskiej UG. Zajmuje się literaturoznawstwem polskim i niemieckim, komparatystyką oraz teorią przekładu. Autorka monografii Obraz świata i konwencja literacka w przektadzie. O niemieckich thumaczeniach dziet Adama Mickiewicza (2008; wydanie niemieckie: Das Weltbild und die literarische Konvention als Übersetzungsdeterminanten. Adam Mickiewicz in deutschsprachigen Übertragungen, 2009). Współredaktorka tomów zbiorowych, w tym Translation im Spannungsfeld der „cultural turns” (2013). Publikowała w „Pamiętniku Literackim”, „Ruchu Literackim”, „Polonistyce”, „Convivium”, „Przestrzeniach Teorii”.

e-mail: katarzyna.lukas@wp.pl 